\title{
State Commitment in Reducing Greenhouse Gas Concentration Based on Paris Agreement
}

\author{
Edgar Michael Parinussa ${ }^{1}$, Edmondus Sadesto Tandungan ${ }^{2}$ \\ Faculty of Law, Universitas Kristen Indonesia Paulus ${ }^{1,2}$
}

\{edgarparinussa61@gmail.com $\left.{ }^{1}\right\}$

\begin{abstract}
Climate change has become a global issue that has been hotly discussed in the last 20 years. In general, climate change occurs due to an increase in the earth's temperature caused by an increase in the concentration of Greenhouse Gases (GHG) in the earth's atmosphere. This is what encourages the international community to form international policies related to the commitment of countries to reduce GHG concentrations with the formation of the United Nation Framework Convention on Climate Change (UNFCCC) which will build a common framework to tackle climate change. This study aims to determine the strategies and steps taken by several countries in reducing GHG concentrations. This study uses normative method with a statutory approach and a comparative approach. The results in this study indicate that the target for reducing GHG concentrations is different for each country, which is greatly influenced by the national interests of each country.
\end{abstract}

Keywords: Climate Change; Greenhouse Gases; State Commitment

\section{Introduction}

Climate change as a result of global warming become a serious international topic and get a special notice from the international community. This climate change is a consequence of human activities causing changes in the composition of the atmosphere globally. In general, climate change occurs due to an increase in the earth's temperature because of rising the concentration of Greenhouse Gases (GHG) in the earth's atmosphere. Basically, the effect of GHG is a natural phenomenon that provides many benefits for survival on earth, because it plays a role in warming the earth, where solar thermal radiation is trapped in the earth's atmosphere.

However, the problem that then arises is if the concentration of GHG in the air increases and conduce much more heat being trapped on earth. This clearly has an impact on the temperature of the earth which is increasing and has negative implications for the population of living things. The main gases categorized as GHG are carbon dioxide $(\mathrm{CO} 2)$ and methane (CH4), because these gases dominate the concentration of GHG in the atmosphere. In addition, there are also other GHGs that are more dangerous than $\mathrm{CO} 2$ and $\mathrm{CH} 4$ gases in small concentrations, including Nitrogen Oxide (NOx), Hydrofluorocarbons (HFCs), Perfluorocarbons (PFCs), Chlorofluorocarbons (CFCs) and Sulfur Hexafluoride (SF6). According to the Intergovernmental Panel on Climate Change (IPCC), the levels of 
greenhouse gases in the earth's atmosphere are 60 percent $\mathrm{CO} 2,15$ percent $\mathrm{CH} 4,11$ percent CFCs, 4 percent NOx, and 9.5 percent other gases.

Any time of human activities contribute GHG emissions, especially $\mathrm{CO} 2$ to the atmosphere, conduce in an increase in the concentration of GHG in the atmosphere which has an impact on increasing temperatures and causing climate change. Climate change has a very serious impact and threatens the lives of living things on earth, including melting icebergs, rising sea levels, extreme weather, and so on. Based on Article 1 point 5 Article UNFCCC means that Climate changes means a change of climate which is attributed directly or indirectly to human activity that alters the composition of the global atmosphere and which is in addition to natural climate variability observed over comparable time period.

Climate change caused by increasing concentrations of GHG has been a concern of scientists since the 1960s and continues to this day. The international world also pays great attention to phenomena and brings a negative impact for life on this earth. As response to this phenomenon, the results of the conference of leaders in the world (Earth Summit) in Rio de Janeiro, Brazil in 1992 established the United Nations to form a world body called the United Nation Framework Convention on Climate Change (UNFCCC) which would build a common framework to address change. climate. At the third Conferences of the Parties (COP) in Kyoto, Japan, in 1997 a joint agreement was made known as the Kyoto Protocol, which the agreement came into force on February 16, 2005.

The reason behind the formation of the Kyoto Protocol is related to the problem of climate change caused by massive industrial activities for 150 years. The purpose of establishing the Kyoto Protocol is as stated in Article 2 of the UNCCC, namely to stabilize the concentration of greenhouse gases at a level that does not endanger the earth's climate system. Basically, the Kyoto Protocol intends to unify commitments related to tackling the problem of climate change by obtaining recognition from developed countries to be responsible for high levels of GHG emissions as a result of these industrial activities. For this reason, in this Protocol, developed countries are positioned as bearers of the problem of reducing greenhouse gas emissions and initiating commitments for countries in the world to commit on overcoming the problems of climate change.

Countries who ratify this Protocol commit to reduce emissions of $\mathrm{CO} 2$ and five other greenhouse gases, or to cooperate in emissions trading if they maintain or increase emissions of these gases, which have been linked to global warming. In 2008, 183 countries have ratified the Kyoto Protocol. This means that countries that have ratified the Kyoto Protocol must follow all the rules written in the Protocol and be willing to accept sanctions if they violate them. Initially, the application of the Kyoto Protocol itself can be said to be ineffective, given that there is a tug of interest, especially by developed countries which are the largest contributors to GHG emissions. This is because the number of developed countries that have ratified it has not met the requirements for reducing GHG emissions. Of the developed countries that have ratified it, there are 24 countries whose emission reductions have only reached 43 percent of the minimum effective emission reduction target of 55 percent.

However, in various COPs, participating countries have conveyed their commitments on the target to reduce their country's GHG concentration. For sure, the targets given by each country are different because they are based on the conditions and national interests of each country. Thus, this article tries to analyze what commitments the state has to reduce GHG concentrations as well as to see the policies taken by the state to achieve the commitment targets. 


\section{Method}

The type of research used in this research is normative legal research with comparative approach. The data used in this article are secondary data in the form of primary legal materials, namely international legal norms, namely the Kyoto Protocol, and secondary legal materials, namely literature in the form of books, journals, and related articles. The data analysis in this article uses a qualitative analysis by describing the facts, then analysis is carried out based on international legal norms and existing theories.

\section{Results and Discussion}

\subsection{The International Response to Decreasing GHG Concentrations}

Concern about the impact of global warming related to global climate change, encourages for international cooperation to control by reducing the effect of greenhouse gases (GHG). In this case, climate change is the collective responsibility of the human community of all nations. The inventory of "international environmental legal instruments" finds more than 500 international environmental treaties. In reality, various forms of international agreements in the environmental sector have developed including hard law and soft law, so it is necessary to have clarity on the form and nature of the international agreements whether they are soft law or hard law.

Based on the UN General Assembly Resolution 2398 (XXIII) on the United Nations Conference on the Human Environment, the United Nations organized the Environment Conference in Stockholm in 1972. This conference was "Action Oriented", which was oriented towards practical actions to protect the environment and produced a declaration, namely the Stockholm Declaration of 1972 (Declaration of the United Nations Conference on the Human Environment) which contains 26 principles of environmental management and protection, 109 recommendations, including an institutional system responsible for implementing the declaration.

In 1985, the international community held a meeting in Vienna and produced a Convention on the Protection of Ozone (Vienna Convention for the Protection of the Ozone Layer). This meeting was followed by the 1987 Montreal meeting and resulted in additional provisions for the 1985 Vienna Convention, namely the 1987 Montreal Protocol (Protocol on Substances that Deplete the Ozone Layer). In 1992, a conference of leaders in the world (Earth Summit) was held in Rio de Janeiro, Brazil which at the conference set the UN to form a world body called the United Nation Framework Convention on Climate Change (UNFCCC) with the awareness that the convention could become a foundation strong force to face the problem of climate change.

To implement the convention, the framework for protecting the atmosphere at the level of international environmental law requires clarity on the legal status of its regulation, as expressed by David Pocklington that "The legal status of the principle of common but differentiated responsibility in international environmental law and, in particular, within the climate regime is subject to dispute. " All commitments and implementation steps to address global warming and climate change due to air pollution must be based on legal policies that are juridically constructed in international environmental law instruments. To realize the goals and implement the UNFCC, Article 3 of the UNFCC regulates the principles that become the basis for achieving stable GHG concentrations, namely: 
a. Common but differentiated responsibilities, is responsibilities but different according to the capabilities of the parties.

b. Special considerations for disproportionately burdened developing countries, is the special needs and circumstances of developing countries that are prone to climate change which must bear a burden that is disproportionate to or beyond its reach that deserves full attention.

c. Scientific uncertainty is not an excuse for inaction, is scientific uncertainty cannot be used as an excuse to delay action to reduce the causes of global climate change.

d. Cost effective policy response, is policies related to climate change must be based on cost effectiveness (the lowest possible cost).

e. Responses may be carried out cooperatively, is cooperation with interested parties to develop an international economic system towards sustainable development for all convention participants, especially developing countries in facing the problem of climate change.

f. Promotion of sustainable development, which is to initiate the implementation of sustainable development to tackle climate change.

g. No distortion of international trade, is the prohibition of covert international trade restrictions (to combat climate change) including those that are unilateral in nature, should not be a means of arbitrary acts or discrimination irresponsibly.

As the basis for the implementation of the Convention, a Protocol called the Kyoto Protocol was formed based on a series of talks by member countries of the Convention regarding the establishment of a series of plans to clarify the commitments of these countries. This protocol was adopted on 11 December 1997 and opened for signature on 16 March 1998. This protocol was prepared to set emission reduction targets and emission reduction time targets for developed countries, while developing countries were not given the obligation to reduce emissions. In carrying out their obligations, countries are divided into two Annexes. Annex I for countries that are obliged to reduce their emissions by a certain number which is generally carried by developed countries and countries in transition. Meanwhile, non-Annex countries, which are generally developing countries, are not burdened with the obligation to reduce emissions but must report their emission status and can participate in reducing emissions through cooperation with countries included in Annex I.

In the First Period, the Kyoto Protocol specifically stipulated that countries listed in Annex I of the UNFCCC had an obligation to reduce GHG emissions by 5 percent within five years from 2008 to 2012. The United States was targeted to reduce ODS by 7 percent, Japan 6 percent and the European Union 8 percent. This policy is reasonable, considering that developed countries are the largest contributor to the increase in GHG concentrations. Through this emission reduction target, the main targets in the Kyoto Protocol are:

a. Binding legally (legally binding)

b. There is a commitment period(commitment period)

c. The assigned amount for each Annex I party is used

d. Inclusion of six types of GHG (basket of gases)

The discussion on problems in implementing the Kyoto Protocol is a long series of negotiations carried out at the Conference of the Parties (COP). At the COP in Bonn, a fundamental formula was produced which became known as the Bonn Agreement. This agreement establishes several main references in the application program for the Kyoto Protocol. Some of these provisions are related to the funding system, the mandatory technology transfer from developed to developing countries, and flexible mechanisms to be implemented in the implementation of the Kyoto Protocol. With regard to funding, it is 
stipulated that countries included in Annex I must provide new funding for developing countries. Funding is carried out through Global Environmental Facilities (GEF), bilateral and multilateral donor agencies, and the provision of special funds for climate change.

These funding activities include capacity building, adaptation, technology transfer, energy, transportation, industry, agriculture, forestry, waste management, and other activities to help developing countries improve their economies. In terms of a flexible mechanism as stipulated in the Bonn Agreement, it consists of three things, namely Joint Implementation, Emmisions Trading, and Clean Development Mechanism. This mechanism is one way for developed countries to reduce GHG emissions abroad. However, the use of this mechanism is only additional for domestic GHG emission reduction activities.

Joint implementation (JI) is a mechanism that allows developed countries to build joint projects that can generate credits for reducing or absorbing GHG emissions. Emmision Trading (ET) is a mechanism that allows a developed country to sell GHG emission reduction credits to other developed countries. ET can be made possible when developed countries that sell GHG emission reduction credits have GHG emission reduction credits that exceed their country's target. Clean Development Mechanism (CDM) is a mechanism that allows nonANNEX I countries to take an active role in helping reduce GHG emissions through projects implemented by a developed country. Later the GHG emission reduction credits generated from the project can be owned by these developed countries. CDM also aims for developing countries to support sustainable development, besides CDM is the only mechanism through which developing countries can participate in the Kyoto Proto.

In relation to the three concentration reduction mechanisms stipulated in the Kyoto Protocol, the responsibility carried uses the concept of "common but differentiated responsibility", in which the responsibility is mainly to developed countries as the largest GKR emitters. Based on this concept, the Joint Implementation and Emission Trading mechanisms are carried out more by developed industrial countries than developing countries. Meanwhile, in the Clean Development Mechanism, developed countries provide assistance to developing countries through environmentally friendly development.

Considering that there were still developed countries that did not implement the Kyoto Protocol agreement, the Bonn Agrement then formed a Unity Committee which aims to correct non-compliance, to ensure environmental integrity and also to provide incentives for compliant member countries. The Compliance Committee includes a facilitative branch and an enforcement branch. The function of the facilitative branch is to provide advice and facilitate the implementation of compliance, as well as provide advance warning of noncompliance actions. The reinforcement branch serves to provide sanctions for noncompliance. The sanctions given to Annex I countries that do not carry out their commitments are:

a. Interpolation 1.3 times of country's total emissions in the first commitment period will be treated as the total emissions assigned to the commitment in the second period.

b. Develop a compliance plan

c. Suspension for not trading in emissions.

At the UNFCCC COP 18 meeting in Doha Qatar in 2012, the implementation of the Kyoto Protocol was extended until 2020. The second commitment in this session was agreed to increase GHG emission reduction to 18 percent by 2020 by applying the same principles and mechanisms as the previous period. In 2015, through the 21st COP in Paris, 195 countries participating in the United Nations High Level Conference on Climate Change agreed to the Paris Agreement, which is an international agreement related to GHG emission reduction efforts that will take effect after 2020. In the conference, five basic things were agreed, First, 
mitigation efforts by rapidly reducing emissions to reach the threshold for increasing the earth's temperature, which is below 2 degrees Celsius and efforts to reduce it to 1.5 degrees Celsius. Second, a transparent carbon accounting and emission reduction system. Third, adaptation efforts by strengthening the ability of countries to cope with the impacts of climate change. Fourth, strengthen efforts to recover from damage caused by climate change. Fifth, assistance, including funding for countries to build green and sustainable economies.

According to Maljen-Dubois, international agreements as a substitute for the Kyoto Protocol must be within the framework of the United Nations Framework Convention on Climate Change applying applicable to all principles, multilateral in nature and the regime must be based on rules and based on protocol provisions, another legal instrument or an agreed outcome with legal force. The Paris Agreement is considered successful by using the applicable for all approach, because it reflects broader participation and guarantees developed countries to commit to reducing emissions by 2030. Based on this approach, member countries convey their commitment to reducing GHG emissions through an Intended Nationally Determined Contribution (INDC). Therefore, Article 3 of the Paris Agreement states that the parties must take ambitious action through the determined national contribution (NDC) and observe developments from time to time and pay attention to the needs of developing countries. This is in line with the statement in the Paris Agreement which recognizes the importance of the involvement of all levels of government and various actors, in accordance with the national laws and regulations of each party, in addressing climate change.

\subsection{State Commitment and Responsibility for Reducing GHG Emissions}

International law is what governs an independent and sovereign state, where international law consists of a set of laws which mostly consist of principles and rules of behavior that bind the state. Therefore, international law must be obeyed in relations between countries. In the development of international law, agreements entered into between countries have a very basic role and international treaties themselves become a source of international law. International agreements are also a means for all countries to develop peaceful cooperation, and the ability to develop this cooperation is an inherent attribute of a sovereign state. According to Anzilotti's teaching, international treaties are binding based on the principle of "pacta sunt servanda" as stated in (article 26 Vienna Convention 1969). This principle is also in accordance with the London Declaration of 1871 which states that countries recognize the principle of international law which stipulates that states cannot differentiate themselves from international treaties or change their provisions without the agreement of the opposing parties promised through friendly mutual understanding.

Similary with the UNCCC which is one of the international agreements that binds all countries that ratify it. Article 3 of the UNCCC lists the principles that underlie state actions in reducing GHG concentrations, namely the principle of equality, mutual but different responsibility, precautionary action, and sustainable development. Even though the initial implementation of the Kyoto Protocol was rejected by developed countries, the Paris Agreement provided a breath of fresh air for efforts to reduce GHG emissions, reflecting the wider participation of developed countries. Through this agreement, the goal of forming the UNCCC to stabilize the concentration of greenhouse gases at a level that does not endanger the earth's climate system can be realized.

As a follow-up to the United Nations Summit on Climate Change in Paris, a number of countries have expressed their commitment to reducing GHG concentrations through a Nationally Determined Contribution (NDC) plan as a concrete form that will be carried out in 
order to achieve the highest objectives of the Convention. This commitment made by each country creates responsibility for the country concerned in reducing GHG emissions. State responsibility is a fundamental principle in international law, which arises when there is a violation of an international obligation to do something, whether that obligation is based on international agreements or based on international customs. In international law, there are two types of rules, namely First, Primary Rules which are a set of rules that define the rights and obligations of the state as stated in the form of treaties, customary law or other instruments. Second, Secondary Rules, which are a set of rules that define how and what legal consequences are if the primary rules are violated by a country. These secondary rules are known as the law of state responsibility.

\section{a) Commitment of Malaysia}

Malaysia has issued the Malaysian Raodmap and Challengers on Implementation of the Intended Nationally Determined Contribution (INDC) as an effort to reduce GHG concentrations. Basically, Malaysia has made several efforts to reduce GHG before ratifying the Paris Agreement which is divided into several periods. To realize this, Malaysia continues to allocate financial resources to its climate change implementation program through public and private sector initiatives. These policies are implemented together with national priorities such as poverty eradication, improving the quality of life and development. In addition, financial resources are often allocated to cover losses due to increased incidence of natural disasters.

In the period 2005-2010, several steps were taken by Malaysia, namely increasing the use of non-fossil fuel energy, where in 2006 Malaysia implemented a National Biofuel policy. This policy was then continued by enacting the National Biofuel Industry Law in 2007, and at the end of 2014 was able to introduce the B7 Bio-Diesel Program. During the period 2011 2015, Malaysia began to design a strategy to further reduce GHG emissions with a Renewable Energy policy by establishing a Renewable Energy Law. In addition, the Malaysian Government also carries out sustainable forest management and the use of natural resources.

As a follow-up to the Paris Agreement, Malaysia has a commitment contained in the NDC to reduce GHG concentrations by 45 percent of total national emissions by 2030, which consists of reducing GHG emissions by 35 percent on an unconditional basis, and 10 percent with assistance from developed countries in the form of financing, technology transfer and capacity building. To fulfill the obligations under the Paris Agreement, the Government of Malaysia, through the Ministry of Natural Resources, is working with the United Nations Development Program (UNDP) Malaysia and stakeholders at the national and local levels in formulating a roadmap for implementing INDC. UNDP Malaysia recruited consultants to formulate a roadmap identifying significant sectors for reducing GHG emissions.

In addition, the Malaysian Government is implementing a strategy of strengthening the environment through preserving nature and resilience of natural resources against climate change and disasters. One of them is the Industry Awareness Program in the form of a Green Industry which aims to create awareness in order to ensure that the manufacturing industry can be responsible and follow Malaysia's commitments in the Paris Agreement. This program is also intended to identify constraints faced by industry and increase capacity in the context of climate change mitigation and adaptation. The forms of Green Industry application include energy conservation, resource and energy efficiency, the use of green labels on products in supermarkets, and so on. The Malaysian government also offers tax incentives in the application of green technology in this industry. 


\section{b) Commitment of the Philippines}

As a form of commitment based on the Paris Agreement, the Philippines issued a National Contribution (NDC) by reducing the GHG concentration by 70 percent in 2030 from the energy, transportation, forestry, industry and waste sectors. This reduction target is based on financial resources, including technology development and transfer, and capacity building. To realize its GHG emission reduction commitment, the Philippines prioritizes adaptation programs by implementing various steps, namely strengthening institutions and systems to conclude climate change models, creating scenarios, monitoring and observing climate.

Adaptation programs are also carried out by providing knowledge-based data on climate risk in reducing disaster risks to development plans and developing disaster-resilient ecosystems; climate and disaster resilience enhancement is carried out in the main sectors, namely agriculture, water, and health; and research and development on climate change.

\section{c) Commitment of the Chinese State}

At the time of ratifying the Kyoto Protocol in 2002, China was categorized as a developing country and had no special obligation to reduce GHG concentrations. However, today, China is a very developed industrial country that has a major contribution to increase GHG emissions. In an effort to reduce GHG emissions, China implements a Clean Development Mechanism (CDM), such as cooperation with the European Union in the energy sector. CDM is a step taken by China to always improve its technology to reduce domestic emissions. In addition, China also obtained technology transfers, such as Flue Gas Desulphurisation, low NOx combustion, and Ultra Clean Coal.

Through the CDM, the Chinese government implements various policies, namely the Upgraded Brown Coal policy on coal. Through this policy, the use of coal for generation is much more efficient. Another policy is the application of clean technology before combustion, namely the Fluidized Bed Combustion (FBC) technology which is applied to paper mills and power plants, where this technology is effective in reducing emissions by 40 percent to 70 percent. Other policies implemented by the Chinese government are clean technology after the combustion process, carbon capture, closing factories, limiting the use of plastic bags, and enforcing vehicles by limiting ownership of the number of cars.

Based on the INDC, China has committed to reduce GHG emissions by 60 percent to 65 percent by 2030.The steps taken are to increase the share of non-fossil fuels in primary energy consumption to around 20 percent, increasing the volume of forest stocks by around 4.5 billion meters. cubic. In addition, China also continues to proactively adapt to climate change by enhancing mechanisms and capacities to effectively cope with climate change risks in key sectors such as agriculture, forestry and water

\section{d) Indonesia}

Indonesia's commitment to reducing GHG concentrations has been seen since Indonesia ratified the UNFCCC through Law Number 6 of 1994 concerning the United Nations Framework Convention on Climate Change and ratification of the Kyoto Protocol through Law Number 17 of 2004 concerning Ratification of the Kyoto Protocol to the Framework Convention United Nations on Climate Change. Indonesia is also the first developing country to associate itself with the Copenhagen Accord. In fact, Indonesia is a developing country that 
voluntarily makes commitments to reduce GHG emissions, although basically Indonesia does not have a special obligation to reduce GHG emissions.

Indonesia has ratified the Paris Agreement through Law Number 16 of 2016 concerning Ratification of the Paris Agreement to the United Nations Framework Convention on Climate Change. Based on this law, Indonesia is binding and obliged to implement the agreement in the Paris Agreement. In the explanation of Law Number 16 of 2016, it is stated that the benefits of ratifying the Paris Agreement are:

1. Increasing the protection of Indonesia's areas that are highly vulnerable to the impacts of climate change through climate change mitigation and adaptation.

2. Increased recognition of national commitments in reducing emissions from various sectors, preserving forests, increasing renewable energy and the participation of local communities and indigenous peoples in controlling climate change that Indonesia has been fighting for so far.

3. Become Parties that can participate (have voting rights) in making decisions related to the Paris Agreement, including in developing modalities, procedures and guidelines for implementing the Paris Agreement.

4. Obtain easy access to sources of funding, technology transfer, capacity building for the implementation of mitigation and adaptation action

Indonesia's Nationally Determined Contribution (NDC) covers aspects of mitigation and adaptation. In line with the provisions of the Paris Agreement, Indonesia's NDC needs to be determined periodically. In the first period, Indonesia's NDC target is to reduce emissions by $29 \%$ on its own and to $41 \%$ if there is international cooperation from a business as usual condition in 2030, which will be achieved, among others, through the forestry sector, energy including transportation, waste, industrial processes and product use, and agriculture. Indonesia's NDC commitment for the next period is determined based on a performance review and must show improvement from the next period.

Indonesia's Nationally Determined Contribution (NDC) covers aspects of mitigation and adaptation. As a follow-up to this commitment, the Indonesian National Action Plan for Greenhouse Gas Emission Reduction (RAN-GRK) government provides a policy framework and guidelines for the central government, local governments, stakeholders and business actors in its implementation. The GHG emission reduction target consists of the forestry and land / ecosystem sectors (17.2 percent), then the energy sector (11 percent), waste (0.38 percent), agriculture ( 0.32 percent) and industry and factories $(0.10$ percent $)$. As for adaptation, Indonesia's commitments include increasing economic resilience, social resilience and livelihoods, as well as ecosystem and landscape resilience.

In achieving the 29 percent target, Indonesia has good modalities in fulfilling the NDC promise, namely through its policies and regulations, as well as the activities and roles of institutions in supporting funding, capacity building, technology transfer, partnerships, and research. In the energy sector, the government focuses on reducing emissions through an energy use efficiency strategy, utilizing clean coal technology (CCT), renewable energy, electricity production based on EBT, and so on. Meanwhile, in the industrial sector, energyintensive industries have made their activities more environmentally friendly. Policies implemented to support the National Action Plan for Greenhouse Gases (RAN GRK) in the forestry and peatland sectors are:

1. Reducing GHG emissions by simultaneously increasing environmental comfort, preventing disasters, absorbing labor, increasing community and state income.

2. Management of network systems and water systems in swamps.

3. Maintenance of the swamp reclamation network (including existing peat lands). 
4. Increased productivity and efficiency of agricultural production on peat lands with the lowest possible emission and optimal absorption of $\mathrm{CO} 2$.

Policies in the transportation sector are ;

a. Saving in the use of final energy either through the use of more efficient technology or by reducing energy consumption.

b. Use of cleaner fuel (fuel switching).

c. Increasing the use of new and renewable energy (EBT).

d. Utilization of clean technology for both electricity generation and transportation facilities.

e. Development of a national mass transportation that is low emission, sustainable and environmentally friendly.

\section{Conclusion}

Global warming caused by the increased of GHG concentrations has become a major concern of the international community, which is manifested in the International Convention on Climate Change which was later derived into the Kyoto Protocol. Various dynamics related to the regulation in the Kyoto Protocol had caused pessimism towards efforts to reduce GHG concentrations. Moreover, the tug-of-war experienced in various COPs, shows that the commitment to reduce GHG concentrations, especially by developed countries is still lacking. Developed countries think that the Kyoto Protocol is more of a political effort, especially from developing countries. Despite the rejection through various efforts, finally through the Paris Agreement developed countries firmly stated their commitment to reducing the GHG concentration. This is manifested in the NDC statement of each country at the High Level Conference in Paris. The GHG emission reduction target in each country also varies, which this case based on the conditions and national interests in each country.

\section{References}

[1] Sri Soewasti Soesanto, "Gas Rumah Kaca", Media Litbangkes.Vol. 5, No. 3, 1995, p. 27

[2] United Nations Environment Programme, Handbook of Environmental Law, United Kingdom, in Suparto Wijoyo. (2009). "Dinamika Komitmen Internasional Dalam Kerangka Pengendalian Global Warming", Jurnal Legislasi Indonesia, Vol. 6, No. 1,2009 , p. 19

[3] Marsudi Triatmodjo, "Implikasi Berlakunya Protokol Kyoto 1997 Terhadap Indonesia", Jurnal Hukum Internasional.Vol. 2. No, 2005, p. 295

[4] Vigayanti Fattah, "Pengaturan dan Tanggungjawab Negara Terhadap Global Warming dalam Protocol Kyoto 1997”, Fiat Justitia Jurnal Ilmu Hukum.v7n1, 2013, p. 7

[5] Otto Soemarwoto. (1992). "Indonesia Dalam Kancah Isu Lingkungan Global", Jakarta: PT Gramedia Pustaka Utama, Jakarta, 1992, p. 140.

[6] Daud Silalahi.(1996)."Sustainable Development in Indonesia: National, Regional anda International Environmental Law". Indonesian Journal of Environmental Law, Edition 1, 1996, p. 43 
[7] Andreas Pramudianto, "Hukum Perjanjian Lingkungan Internasional: Implementasi Hukum Perjanjian Internasional Bidang Lingkungan Hidup di Indonesia", Malang: Setara Press, 2014.

[8] Suparto Wijoyo, Op.cit. p. 21

[9] Ibid. p. 29

[10] Daniel Murdiyarso, "Protokol Kyoto Implikasinya Bagi Negara Berkembang", Jakarta: Penerbit Buku Kompas, 2007, p. 854

[11] Andreas Pramudianto, "Dari Kyoto Protocol 1997 Hingga Paris Agreement 2015: Dinamika Diplomasi Perubahan Iklim Global Dan ASEAN Menuju 2020”. Global Vol. 18, No. 1, 2016, p.79-80.

[12] Lavanya Rajamani. "The Principle of Common but Differentiated Responsibility and the Balance of Commitments under the Climate Regime", Review of European, Comparative and International Environmental Law, Vol. 9. No.2, 2000, p. 127

[13] Supriadi, "Hukum Lingkungan Internasional”, Jakarta: Penerbit Sinar Grafika, 2006, p. 71

[14] Marsudi Triatmodjo, Op.cit. p. 300

[15] Ibid, p. 301

[16] https://www.wwf.or.id/tentang_wwf/upaya_kami/iklim_dan_energi/

[17] Marsudi Triatmodjo, Op.cit, p. 302

[18] Andreas Pramudianto, Op.cit, "Dari Kyoto Protocol 1997...", p. 84

[19] Ibid, p. 86

[20] Sumaryo Suryokusumo, "Hukum Perjanjian Internasional", Jakarta: Tatanusa, 2008, p. 6

[21] Ibid, p. 29

[22] Sefriani. "Hukum Internasional: Suatu Pengantar", Jakarta: PT. Raja Grafindo Persada, 2010 , p. 266.

[23] https://www4.unfccc.int/sites/submissions/INDC/Published\%20Documents/Malaysia

[24] Ibid

[25] https://www4.unfccc.int/sites/submissions/INDC/Published\%20Documents/Philippines

[26] www.hukumonline.com/pusatdata

[27] Ibid

[28] https://www.bappenas.go.id/files/3613/5029/1386/kebijakan-nasional-mitigasi-danadaptasi-perubahan-iklim 